\title{
Reproductive efficiency in lactating mares inseminated early in the puerperium ( $<10$ days post partum) versus non-lactating mares inseminated 180 days post partum
}

\author{
Carlos Edvardo Camargo', Luiz Ernandes Kozicki', Paulo César Ruda², Victor Breno Pedrosa ${ }^{3}$, Rafaela Talini', \\ Romildo Romualdo Weiss ${ }^{4}$, Tácia Gomes Bergstein-Galan ${ }^{4}$ and Rudiger Daniel Ollhoff' \\ Animal Science Graduate Program, School of Life Sciences, Pontifícia Universidade Católica do Paraná, Curitiba, Brazil \\ 2 Autonomous Veterinarian \\ 3 State University of Ponta Grossa, Paraná, Brazil \\ 4 Federal University of Paraná, Curitiba, Paraná, Brazil
}

\begin{abstract}
Summary: To achieve the desired reproduction rate of one foal per year per mare and to optimize the reproductive potential of mares that are embryo donors, foal heat should be utilized as a tool for improvement of fertility. The mare is the only domestic animal showing ovulatory estrus shortly after foaling. The uterine involution and the ovarian activity (post partum follicular dynamic) in the early puerperium go through brief periods of time. Fetal expulsion at physiological delivery occurs within a short time and the placenta is expelled few hours later. Such events in the intra- and peri-partal period may be also related to the type of histological tissue that composes the cervix in these animals. The mare's cervix (muscular type) has a fantastic speed related to uterine involution, unlike the other species in domestic animals (cervix fibro-cartilaginous type) (more resistant requesting more time to involute). Nonetheless, fertility during foal heat is reported to be by some authors better or similar or even lower than fertility during heat outside this period. There are still some controversies on this matter, so we hypothesized that non-lactating mares have a greater potential for pregnancy rate than that lactating mares in foal heat, because the uterine involution is already finalized and ovarian activity is basically normalized in non-lactating mares, opening greater possibilities to became pregnant. In Southern Brazil, the Criollo breed (an original cross between Andalusian and Berber breeds) is a well stablished and widely used breed of horse, as it adapted well to the features of the Brazilian climate under field conditions, and developed two useful abilities (too much for work, and sports). To improve the reproduction mainly in Criollo horses, this study aimed to compare the pregnancy rate (PR) and other reproductive parameters (parturition-artificial insemination interval; parturition-ovulation interval; diameter of preovulatory follicle; artificial insemination-ovulation interval) between lactating mares in early puerperium and non-lactating mares artificially inseminated (Al) $\geq 180$ days postpartum. This study took place at a stud farm in Southern Brazil between September and December (breeding season). Thirty-one mares Criollo breed, multiparous with mean age 9.6 years (range 6-14) and body condition score (BCS) 3.1 ( $1=$ thin, $5=$ obese) were divided into two groups: lactating mares (LMs) subjected to $\mathrm{Al}<10$ days postpartum $(\mathrm{n}=16)$ and non-lactating mares $(\mathrm{NLMs}) \mathrm{Al} \geq 180$ days postpartum $(n=15)$. The mares were selected based on clinical criteria (absence of clinical endometritis or abnormal uterine discharge and by parturition date). Both groups had the same environment and nutritional conditions. The ovaries were examined by ultrasonography every other day; after detection of a follicle $\geq 30 \mathrm{~mm}$ in diameter (= the sum of the larger and smaller diameter divided by 2), the examinations with ultrasonography were conducted daily. After the detection of follicles $\geq 35 \mathrm{~mm}$, uterine edema, and open cervix, both groups received 1500 IU of human chorionic gonadotrophin (hCG). After 24 hours, Al was performed (fresh semen from two fertile stallions. After 15 days, pregnancy diagnosis was performed. The models were fitted in the Statistical Analysis System software (SAS). To evaluate (in LMs and NLMs) the influence of treatment on the diameter of the preovulatory follicle and on insemination-ovulation interval, the General Linear Model procedure for analysis of variance (ANOVA) with the F-test was carried out. Additionally, the correlations among the animal's age, parturitionovulation interval, and the diameter of the preovulatory follicle were estimated to verify their possible influence on one another. The correlation was estimated by the CORR procedure in SAS. Finally, the data were presented as mean \pm standard error, and the significance level was set to $5 \%$ for all the statistical tests. The parturition-insemination interval and parturition-ovulation interval were 7.8 and 9.3 days, respectively (in LMs). All the mares ovulated and the average of every parameter analyzed can be seen on table 1. The average diameter of the preovulatory follicle was 45.0 and $44.5 \mathrm{~mm}$ in LMs and NLMs, respectively. The insemination-ovulation interval was 38.8 and 46.3 hours $(P=0.04)$, and the PR was 56.2 and $46.6 \%(P>0.05)$ in LMs and NLMs, respectively. The hypothesis that NLMs have a greater pregnancy rate than do LMs was not confirmed. On the contrary, the LMs showed a slightly better pregnancy rate than NLM did, suggesting that foal heat can be used for breeding of Criollo mares. In conclusion, no difference in the PR was found between mares inseminated at the early postpartum period and other estruses. LMs showed a shorter insemination-ovulation interval $(P<0.05)$ than NLMs did. No correlation was observed among the diameter of the preovulatory follicle, age, and PR in either group. Furthermore, no correlation was found between age and the foaling-ovulation interval and between the diameter of the preovulatory follicle and foaling-ovulation interval.
\end{abstract}

Keywords: mares, artificial insemination, lactating, non-lactating, foal estrus

Citation: Camargo C. E., Kozicki L. E., Ruda P. C., Pedrosa V. B., Talini R., Weiss R. R., Gomes Bergstein-Galan T., Ollhoff R. D. (2017) Reproductive efficiency in lactating mares inseminated early in the puerperium ( $<10$ days post partum) vs non-lactating mares inseminated 180 days post partum. Pferdeheilkunde 333, 458-464; DOI 10.21836/PEM20170506

Correspondence: Luiz Ernandes Kozicki, Prof. Dr. MSc, School of Life Sciences, Pontifícia Universidade Católica do Paraná, Rua Imaculada Conceição 1155, 80215-901 Paraná, Curitiba, Brazil. E-mail: kozicki.l@pucpr.br

\section{Introduction}

The horse market in Brazil has grown significantly in recent years (to 5.49 million heads) (FAOSTAT 2013), yielding the fourth largest equine population on the planet, and the trade size is close to 4.7 billion US dollars per year (CNA 2015), with approximately 650,000 jobs in this industry. The Criollo breed (concentrated in southern Brazil), is an original cross (between Andalusian and Berber breeds), and was created 
during the Brazilian Colonial period. The breed adapted well to the features of the Brazilian climate under field conditions, and developed two useful abilities (for work and sports). The Criollo horse market alone is $\sim 3.7$ billion US dollars per year, with 238,000 associated jobs (ABCCC 2012).

The duration of mare pregnancy is long. To achieve the reproduction rate of one foal per year per mare and to reduce the interval between foaling and insemination (Blanchard er al. 2012) or to optimize the reproductive potential of mares that are embryo donors (Carvalho et al. 2001, Azevedo et al. 2013), foal heat should be utilized as a tool for improvement of fertility. The mare is the only domestic animal showing ovulatory estrus shortly after foaling (Ginther 1992, Blanchard and Varner 1993). Kozicki and Folchetti (1979) reported the average occurrence of foal heat at 8.9 days postpartum, with the average duration of 6.3 days, and the pregnancy rate of $38.4 \%$, thus corroborating the notion that foal heat occurs within 18 days postpartum, starting from postpartum days 6-10 (Matthews et al. 1967).

The involution of the mare uterus is rapid, in comparison with other domestic animal species. Within 14 days, the uterus returns to the pre-pregnancy state, allowing for manifestation of fertile estrus (Blanchard and Macpherson 2011 ). Nonetheless, fertility during foal heat is still questionable (Blanchard and Macpherson 2011 ). The pregnancy rate during foal heat is similar (Duarte et al. 2002, Azevedo et al. 2013) or lower (McKinnon and Squires 1988, Kurtz Filho et al. 1998, Ishii et al. 2001) than fertility during heat outside this period. The pregnancy rate at 15 days after insemination and the embryonic loss rate between 15 and 60 days after insemination are similar in Mangalarga Marchador recipient mares that were bred during foal heat, in the second postpartum estrus, or in heat without a foal (Gomes et al. 2004).

Malschitzky et al. (2002) analyzed 214 mares (thoroughbreds) and reported that the pregnancy rate during foal heat does not differ from that during subsequent cycles, suggesting that foal heat must be used to maximize the reproductive capacity of breeding mares. Estrus with ovulation before postpartum day 10 shows poor fertility, owing to the inadequate uterine environment when the embryo reaches the uterus (Blanchard and Macpherson 2011). The presence of uterine secretions (lochia) in the early puerperium often results in insufficient uterine involution. This phenomenon appears to be an important reason for the low pregnancy rate in mares with ovulation before postpartum day 15, and may result in embryonic loss (McKinnon and Squires 1988, Ball 2011). Thus, there are still some controversies. We hypothesized that non-lactating mares (NLMs) have a greater potential for pregnancy than do lactating mares (LMs) in foal heat because the uterine involution is already finalized and ovarian activity is basically normalized in NLMs. The aim of this study was to compare the pregnancy rate and other reproductive characteristics between LMs in foal heat that are artificially inseminated with fresh semen in the early postpartum period and NLMs after weaning in the breeding season.

As the study through data collection, it has not been evaluated by a committee of ethics in use of animals put to property issues following all animal welfare principles with a rational management.

\section{Horses and Methods}

This study was conducted through the routine data collection from a stud farm located in southern Brazil (parallel $25^{\circ} 57^{\prime} 41^{\prime \prime}$ southern latitude; 48 19'37' western longitude; Southern Hemisphere) in a temperate climate (Köppen climate classification). Between September and December (breeding season), 31 multiparous mares of the Criollo breed, with mean age 9.6 years (range 6-14) and BCS $3.1 \quad(1=$ thin, $5=$ obese) (Carrol and Huntington 1988), were assigned to one of two groups: LMs (lactating group in foal heat) subjected to artificial insemination $<10$ days after foaling $(n=16)$ and NLMs (non-lactating group without recent foaling) with artificial insemination $\geq 180$ days postpartum $(n=15)$. The mares were selected based on clinical criteria (absence of clinical endometritis or abnormal uterine discharge) and by parturition date (anamnesis).

The animals were kept in a grazing regimen in paddocks (Tifton 85) throughout the year, except for feeding on Lolium multiflorum available in winter. Additionally, the mares were supplied with $1.0 \mathrm{~kg}$ of the concentrated feed (per day per animal) containing digestible energy of $2800 \mathrm{kcal} / \mathrm{kg}, 13.0 \%$ of crude protein, and other ingredients (Equest Supra Animal Nutrition, São Leopoldo, Rio Grande do Sul, Brazil) as well as water and mineral salt (Suprasal Equino 80 Supra Animal Nutrition) ad libitum. LMs were monitored by ultrasonography to examine the follicles (ovaries), uterus, and cervix starting from the second postpartum day (two examinations in 2 days), until detection of follicles $30 \mathrm{~mm}$ in diameter (the sum of the larger and smaller diameter divided by 2) (Gastal et al. 2008), when we started to examine the mares daily (Azevedo et al. 2013). Finding of a follicle $\geq 35 \mathrm{~mm}$ in diameter with simultaneous edema of the endometrium (presence of endometrial folds), uterine tonus (Hayes and Ginther 1986), and the open cervix indicated the right time for intravenous injections of human chorionic gonadotropin (1500 IU HCG; Folligon, MSD, São Paulo, Brazil) to induce ovulation (Winter et al. 2007). Twenty-four hours after the HCG injection, a single artificial insemination (without analysis of ovulation) with fresh semen containing $500 \times 10^{6}$ sperm (dilution with BotuSemen, Biotech, Botucatu, São Paulo, Brazil) from two fertile stallions, was performed.

The artificial insemination was performed after cleaning (with water) and drying of the perineum and vulva (with paper towels) and involved trespassing the cervical canal with catheter insemination aided by introduction of a gloved forefinger by the technician (Mies Filho 1987). Fifteen days after the artificial insemination, a pregnancy test was performed by ultrasonography. The same methodology was used for NLMs (mares that foaled $\geq 180$ days before).

\section{Statistical Analysis}

The models were fitted in the Statistical Analysis System software (SAS, Version 9.1 for Windows; SAS Inst., Cary, NC, USA, 2014). The pregnancy rate, which is a binary variable, had Bernoulli's distribution and was analyzed using mixed logistic regression with the GLIMMIX procedure. The independent variables initially considered in the statistical model were the treatment effect (in LMs and NLMs), the diameter of the 
preovulatory follicle $(<45.0$ or $\geq 45.0 \mathrm{~mm})$, age $(<10$ and $\geq 10$ years), parturition-ovulation interval, and ovulation side (right or left) and their interactions with the pregnancy rate. To obtain the final statistical model, the explanatory variables were sequentially removed based on the statistical criterion of Wald, with the cutoff value of $P>0.2$. According to this criterion, the explanatory variable included in the final model for the pregnancy rate was the treatment effect.

To evaluate (in LMs and NLMs) the influence of treatment on the diameter of the preovulatory follicle and on inseminationovulation interval, the General Linear Model procedure for analysis of variance (ANOVA) with the F-test was carried out. Additionally, the correlations among the animal's age, parturition-ovulation interval, and the diameter of the preovulatory follicle were estimated to verify their possible influence on one another. The correlation was estimated by the CORR procedure in SAS. Finally, the data were presented as mean \pm standard error, and the significance level was set to $5 \%$ for all the statistical tests.

\section{Results}

\section{Evaluation of group effects}

NLMs showed a longer average artificial insemination-ovulation interval as compared to $L M s(P=0.04)$. Nevertheless, the diameter of the preovulatory follicle as well as the pregnancy rate were not significantly different between the two groups $(P>0.05)$.

Main results are shown on table 1. The dispersion graphs and Pearson correlation between some characteristics in LMs are shown in Graphics 1 and 2. Graphic 1 shows the dispersion of data points between age and the parturition-ovulation interval. The correlation between these two parameters was weakly negative $(r=-0.38)$, showing a weak tendency for reduction in the parturition-ovulation interval with the increasing age in LMs.

Graphic 2 shows the dispersion of data points between the diameter of the preovulatory follicle and the parturition-ovulation interval. The correlation between these two parameters was negligible and negative $(r=-0.12)$, meaning almost no relation between these variables.

Graphic 3 shows the dispersion of data points between age and the diameter of the preovulatory follicle. The correlation between these two parameters was weakly positive $(r=0.20)$,

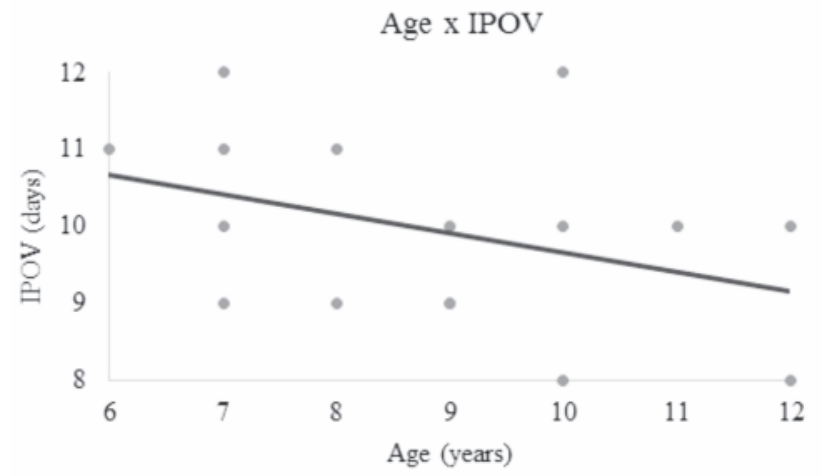

Fig. 1 Dispersion of data points between age and the parturitionovulation interval. | Streuung der Datenpunkte zwischen Alter und Abfohlungs - Ovulationsintervall

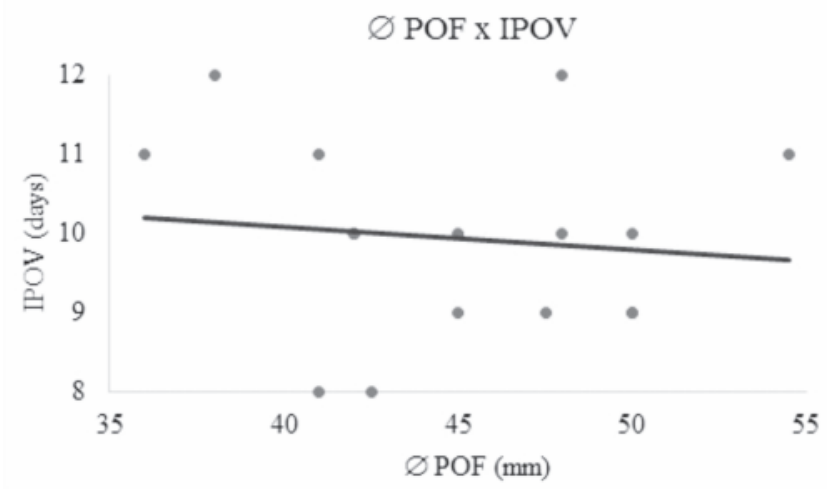

Fig 2 Dispersion of data points between the diameter of the preovulatory follicle and the parturition-ovulation interval. | Streuung der Datenpunke zwischen Durchmesser des präovulatorischen Follikels und des Abfohlungs - Ovulationsintervall

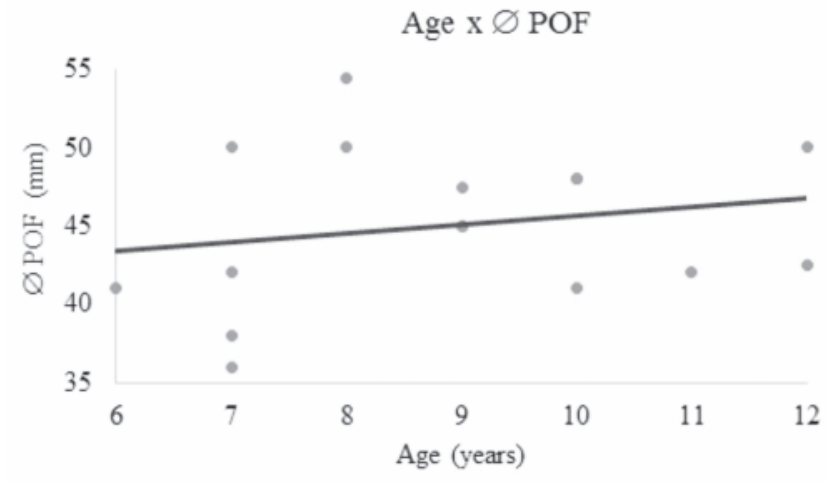

Fig. 3 Dispersion of data points between age and the diameter of the preovulatory follicle. I Streuung der Datenpunke zwischen Alter und Durchmesser des präovulatorischen Follikels

Table 1 Age, the parturition-artificial insemination interval (IP/AI), parturition-ovulation interval (IPOV), diameter of the preovulatory follicle (ØPOF), hCG-ovulation interval, and pregnancy rate (PR) in Criollo lactating and non-lactating mares artificially inseminated with fresh semen. Alter, Abfohlungs-Besamungsintervall (IP/Al), Abfohlungs-Ovulationsintervall (IPOV), Durchmesser des vorovulatorischen Follikels (ØPOF), hCGOvulationsintervall hCG/OV und Trächtigkeitsrate (PR) in laktierenden und nicht laktierenden, künstlich mit Frischsamen befruchteten Criollo Stuten.

\begin{tabular}{ccccccc}
\hline $\begin{array}{c}\text { Mares } \\
\text { (groups) }\end{array}$ & $\begin{array}{c}\text { Age } \\
\text { (years) }\end{array}$ & $\begin{array}{c}\text { IP/Al } \\
\text { (days) }\end{array}$ & $\begin{array}{c}\text { IP/OV* } \\
\text { (days) }\end{array}$ & $\begin{array}{c}\varnothing \text { POF } \\
(\mathrm{mm})\end{array}$ & $\begin{array}{c}\text { hCG/OV } \\
\text { (hours) }\end{array}$ & $\begin{array}{c}\text { PR } \\
(\%)\end{array}$ \\
\hline GL $(\mathrm{n}=16)$ & $8.7 \pm 1.8$ & $7.8 \pm 1.4$ & $9.3 \pm 1.1$ & $45.0 \pm 5.0$ & $38.8 \pm 12.0^{\mathrm{a}}$ & 56.2 \\
$\mathrm{GNL}(\mathrm{n}=15)$ & $10.8 \pm 3.7$ & - & - & $44.5 \pm 5.6$ & $46.3 \pm 6.0^{b}$ & 46.6 \\
P Value & 0.06 & & & 0.79 & 0.04 & 0.59 \\
\hline
\end{tabular}

* All the mares ovulated. Different letters in the same column are significantly different $(\mathrm{P}<0.05)$ 
indicating a weak tendency for an increase in the diameter of the preovulatory follicle with the increasing age. In addition, the data were subjected to Pearson's correlation test (Table 2).

Evaluation of the influence of age $(<10$ or $\geq 10$ years) on the pregnancy rate

Age was subdivided into classes (the only way to evaluate any characteristic compared to the other binomial such as the pregnancy rate (pregnant or not pregnant)). The resulting classes were subdivided by this age cutoff $(<10$ or $\geq 10$ years), because by observing the data, the class that better distributed the " $n$ " between two groups $(<$ and $>$ ).

There was no significant difference $(P>0.05)$ between animals of ages $<10$ and $\geq 10$ years in the pregnancy rate in either group and among all the animals under study (LMs $+\mathrm{NLMs}$ ). Namely, age had no effect on the pregnancy rate.

Evaluation of the influence of the diameter of the preovulatory follicle $(<45$ or $\geq 45 \mathrm{~mm}$ ) on the pregnancy rate

No significant effect $(P>0.05)$ of the diameter of the preovulatory follicle $(<45$ or $\geq 45 \mathrm{~mm}$ ) on the pregnancy rate was found in either group (LMs or NLMs) and among all the animals (LMs+NLMs). Namely, the diameter of the preovulatory follicle did not influence the pregnancy rate.

\section{Other tested characteristics}

The ovulation side (right or left) did not affect the pregnancy rate $(P=0.35)$, the diameter of the preovulatory follicle $(P=0.32)$, or the parturition-ovulation interval $(P=0.56)$. Among $L M s$, the parturition-ovulation interval (age $<10$ or $\geq 10$ ) did not exert a significant influence on the pregnancy rate $(P=0.70)$.

\section{Discussion}

Studies on the use of foal heat in mares that recently foaled (LMs) to achieve the reproduction rate of one foal per year per mare have received a lot of attention among researchers (Nagy et al. 1998, Winter et al. 2007). Recent studies showed that covered mares in the early puerperium (foal heat) have a significantly reduced chance to get pregnant (Blanchard et al. 2012), corroborating the reports of McKinnon and Squires
(1988). Nevertheless, divergent opinions persist on this subject (the use of foal heat) (Camillo et al. 1997). Sharma et al. (2010), after analyzing 228 thoroughbred mares under subtropical climatic conditions, reported that the reproductive performance (pregnancy rate) of artificially inseminated mares in foal heat is not different from that in other subsequent estruses.

Among some of the reproductive parameters addressed in this study, we compared the pregnancy rate after artificial insemination in LMs during foal heat versus the pregnancy rate in NLMs several months after foaling: $56.2 \%$ and $46.6 \%$ $(P>0.05)$, respectively (Table 1$)$. Looking at absolute numbers of artificial inseminations performed on LMs in the early postpartum period, we can see a better pregnancy rate than among NLMs and would like to return to the discussion of fertility in foal heat.

We did not find a plausible explanation to justify the difference of 9.6 percentage points in favor of LMs. Did the length (duration) of the lactation period in NLMs had an effect here, because the mares in this group had nursed their foals for 6 months before the breeding season? Prolonged lactation during constant nursing of a foal can cause gradual depletion of body's resources, and in some way can affect the physical condition and fertility (Aurich 2011). This argument does not apply to LMs during foal heat because these animals are newly foaled and not yet depleted, still having a good physical condition after the pregnancy.

The pregnancy rate among LMs (56.2\%) determined between postpartum days 9 and 10 in this study approaches that reported by Sharma et al. (2010) on postpartum day 16, namely, the pregnancy rate of $53.7 \%$ in LMs and $57.9 \%$ in NLMs (no significant difference between the groups). Winter et al. (2007) studied 19 LMs of the Criollo breed in southern Brazil (29 38' southern latitude) and observed a pregnancy rate of $73.7 \%$ - a result much higher than that obtained in the present study. It is possible that this difference is related, in addition to other causes, to the natural coverage under field conditions (Winter et al. 2007), in contrast to artificial insemination used in this study.

In the present study, the artificial inseminations (in LMs) took place on average on day 7.8 after foaling, and ovulation on day 9.3. The hCG-ovulation interval was significantly different between LMs and NLMs $(P<0.05$; Table 1). Sharma et al. (2010) reported the average time point of 13.6 days for ovulation in thoroughbred mares. Winter et al. (2007) showed a significant range of the foaling-ovulation interval (14.2 days)

Table 2 Correlations among age and pregnancy rate in Lactating (LMs) or Non-Lactating mares (NLMs) artificially inseminated with fresh semen. Korrelation zwischen Alter und Trächtigkeitsrate in laktierenden (LMs) oder nicht laktierenden (NLMs) künstlich mit Frischsamen befruchteten Stuten.

\begin{tabular}{|c|c|c|c|c|}
\hline & \multicolumn{2}{|c|}{$\begin{array}{c}\text { Pregnancy rate } \\
\mathrm{n}(\%)\end{array}$} & \multirow[t]{2}{*}{$P$ value between groups } & \multirow[t]{2}{*}{$\begin{array}{c}\text { Total pregnancy rate }(\mathrm{LM}+\mathrm{NLM}) \\
\text { (n \%) }\end{array}$} \\
\hline & LMs & NLMs & & \\
\hline$\varnothing \mathrm{POF}(<45 \mathrm{~mm})$ & $5 / 7(71.4)$ & $5 / 9(55.5)$ & 0.30 & $10 / 16(62.5)$ \\
\hline$\varnothing P O F(>45$ mm) & $4 / 9(44.4)$ & $2 / 6(33.3)$ & 0.36 & $6 / 15(40.0)$ \\
\hline$P$ value (column) & 0.30 & 0.41 & & 0.22 \\
\hline Age (<10 years) & $5 / 10(50.0)$ & $5 / 8(62.5)$ & 0.60 & 10/18(55.5) \\
\hline Age (>10 years) & $4 / 6(66.6)$ & $2 / 7(28.3)$ & 0.60 & $6 / 13(46.1)$ \\
\hline $\mathrm{P}$ value (column) & 0.52 & 0.22 & & 0.61 \\
\hline
\end{tabular}


among Criollo mares under similar climatic conditions and at a similar temperature and experimental design (field conditions) relative to the present study. We can hypothesize that this discrepancy can be explained by a combination of factors, e.g., the microclimate difference (Nagy et al. 1998), the amount of light per day, food quality, forage intake (Tifton and ryegrass in the present study) versus forage at native field pasture (usually poor quality), dietary supplementation with a concentrate and mineral salt individually provided to the mares (Nagy et al. 1998), and the more homogeneous age (between 6 and 14 years) among the mares in the present study versus the range of 3 to 28 years reported by Winter et al. (2007).

In temperate climates, it is normal for thoroughbred mares to have foal estrus within 10 days and for ovulation to take place within 12 days after foaling (Koskinen 1991, Morris and Allen 2003). In the present study, animals with the diameter of the preovulatory follicle $35 \mathrm{~mm}$ or more were subjected to artificial insemination; this time point is 7.8 days: earlier than the one reported by Kozicki and Folchetti (1979) (8.9 days), by Kurtz et al. (1998) (12.3 days) in thoroughbreds, or by Winter et al. (2007) (13.2 days in Criollo mares). This precocious ovulation after foaling may be associated with the rusticity of the Criollo breed, also supported by the good nutrition available to the mares in this study, in contrast to the Criollo mares studied by Winter et al. (2007).

In the present study, a significant difference $(P<0.05)$ in the hCG-ovulation interval between the two groups was observed. The LMs ovulated earlier (38.8 h) than NLMs did (46.3 h; the difference of almost 8 hours), and the diameter of the preovulatory follicle was slightly greater $(45.0$ versus $44.5 \mathrm{~mm}$; Table 1). It is possible that the diameter of the preovulatory follicle in LMs resulted in better responsiveness to the injected hCG, with a better ovulatory response owing to the greater diameter (and more luteinizing hormone receptors). Larger follicles have higher rates of estrogen production (Course et al. 2005) and a greater number of ovarian receptors of gonadotropins (van der Hurk and Zao 2005). This characteristic seems to have caused the difference in the timing of ovulation between LMs and NLMs. The earlier time point of ovulation after hCG injection led to more synchronization of ovulation, improving the pregnancy rate in LMs. The decrease in the insemination-ovulation interval allowed for better fertilization conditions for gametes (better synchronization between oocyte survival and sperm capacitation) because oocyte viability period in the female genital tract in mares is between 8 to 10 hours (Chang 1951, Hunter 1990).

No correlation was observed among age $(<10$ or $>10.0$ years) and pregnancy rate in either LMs or NLMs (Table 2). The hypothesis that NLMs have a greater pregnancy rate than do LMs was not confirmed. Instead, the LMs showed a slightly better pregnancy rate than NLM did, suggesting that foal heat can be used for breeding of Criollo mares (Duarte et al. 2002, Azevedo et al. 2013).

\section{Conculsion}

It was concluded that there is no difference in the pregnancy rate between the mares artificially inseminated in the early puerperium and mares in subsequent estrus during the bree- ding season. The artificial insemination-ovulation interval in LMs was shorter $(P<0.05)$ than in NLMs. No correlation among the diameter of the preovulatory follicle, age, and pregnancy rate was seen in either group. Furthermore, no correlation was found between the age and foaling-ovulation interval and between the diameter of the preovulatory follicle and foaling-ovulation interval.

\section{Conflict of interest statement}

The author's state no conflict of interest

\section{References}

ABCCC (Brazilian Association of Criollo Horse Breeders). Criollo horse breeding moves more than $\mathrm{R} \$ 1.28$ billion and generates 238,000 jobs in 2012. Available at: http://www.cavalocrioulo. org.br/noticias/detalhes/128719/criacao-de-cavalo-crioulomovimenta-mais-de-r-1-28-bi-e-gera-238-mil-empregos. Accessed on: 28.06.2016

Aurich C. (2011) Reproductive cycles of horses. Animal Reprod. Sci. 124, 220-228; DOI 10.1016/i.anireprosci.2011.02.005

Azevedo R. P., Mendonça I. A., Lanza J. C., Lopes E. P., Gomes P. S., Valle G. R. (2013) Reproductive efficiency in equine embryos transfer using recepients in the foal heat. Rev. Brasil. Reprod. Animal 37, 365-370

Ball B. A. (2011) Embryonic Loss. In Equine Reproduction. Ed A. O. McKinnon, E.L. Squires, W. E. Vaala, D. D. Varner. Ames: Blakkwell. pp. 2327-2338.

Blanchard T. L., Varner D. D. (1993) Uterine involution and postpartum breeding. In: Equine Reproduction. Ed A. O. McKinnon \& J. L. Voss. Lea \& Febiger. pp 622-625

Blanchard T. L., Macpherson M. L. (2011) Breeding mares on foal heat. In: Equine Reproduction. Ed A. O. McKinnon, E. L. Squires, W. E. Vaala, D. D. Varner. Ames: Blackwell. pp. 2294-2301

Blanchard T. L., Thompson, J. A., Love C. C., Brinsko S. P., Ramsey J., O'Meara A., Varner D. D. (2012) Influence of day of postpartum breeding on pregnancy rate, pregnancy loss rate, and foaling rate in Thoroughbred mares. Theriogenology 77, 1290-1296; DOI 10.1016/i.theriogenology.2011.10.034

Camillo F., Marmorini P., Romagnoli S., Vannozzi I., Bagliacca M. (1997) Fertility at the first postpartum estrous compared with fertility at the following estrous cycles in foaling mares and with fertility in non-foaling mares. J. Equine Vet. Sci. 17, 612-616; DOI 10.1016/S0737-0806(97)80189-X

Carroll C. L., Huntington P. J. (1988) Body condition scoring and weight estimation of horses. Equine Vet. J. 20, $41-45$

Carvalho G. R. de, Fonseca F. A., Silva Filho J. M. da, Ruas J. R. M., Borges A. M. (2001) (Evaluation of the use of foal heat in embryo collection). Rev. Brasil. Zootec. 30, 1445-1450; DOI 10.1590/S1516-35982001000600009

Chang M. C. (1951) Fertilization capacity of spermatozoa deposited in the fallopian tubes. Nature 168, 997-998; DOI $10.1038 / 168697 b 0$

CNA (National Agricultural Confederation - Brazil) (2015). Available at: http://www.cnabrasil.org.br. 2015.

Course J. F., Yates M. M., Deroo B. J., Kovach K. S. (2005) Estrogen receptor-beta is criticial to granulosa cell differentiation and the ovulatory response to gonadotropins. Endocrinology 146, 3347-3362; DOI 10.1210/en.2005-0213

Duarte M. B., Vieira R. C., Silva F. O. C. (2002) (Incidence of pregnancy loss until the 50th day in Quarter Horse mares). Ciência Rural 32, 643-647; DOI 10.1590/S0103-84782002000400016

FAOSTAT (FAO Statistical Yearbook 2013). Food and Agriculture Organization of the United Nations, April 2013. Available on: http://faostat.fao.org/site/573/DesktopDefault.aspx?PagelD=57 3\# ancor. Accessed on: 28.06.2016 
Gastal E. L., Neves A. P., Mattos R. C., Petrucci B. P. L., Gastal M.O., Ginhter O. J. (2008) Miniature ponies: 1. Follicular, luteal and endometrial dynamics during the oestrus cycle. Reprod. Fertil. and Develop. 20, 376-385

Ginther O. J. (1992) Reproductive biology of the mare: basic and applied aspects, 2 nd ed. Cross Plains: Equiservices Publishing. 642 p.

Gomes G. M., Jacob J. C. F., Domingues I. B. (2004) Use of mares as embryo recipientes after first postpartum ovulation. Proceedings of an International Symposium: Equine Embryo Transfer. Reading, August 6 to 15, 2004. p. 105

Hayes K. E. N, Ginther O. J. (1986) Role of progesterone and estrogen in development of uterine tone in mares. Theriogenology 25, 581-590; DOi 10.1016/0093-691X(86)90142-1

Hunter R. H. F. (1990) Gamete lifespan in the mare's genital tract Editorials. Equine Vet. J. 22, 378-379

Ishii M., Shimamura T., Utsumi A., Jitsukawa T., Endo M., Fukuda T., Yamanoi T. (2001) Reproductive performance and factors that decrease pregnancy rate in heavy draft horses bred at the foal heat. J. Equine Vet. Sci. 21, 131-136; DOi 10.1016/S07370806(01)70109-8

Koskinen E. (1991) Postpartum ovarian activity in Finnhorse mares with special reference to seasonal effects. Acta Vet. Scand. 32, 313-318

Kozicki L. E., Folchetti M. (1979) Aspects of reproductive control in a group of mares in Jaboticabal Region (breeding season of 1978/1979). Científica Especial, 23-27

Kurtz Filho M., Alda J. L. de, Deprá N. M., Brass K. E., La Corte F. D. de, Silva J. H. S. da, Silva C. A. M., Emanuelli I. P. (1998) (Postpartum fertility in thoroughbred racing mares). Braz. J. Vet. Res. Anim. Sc. 35, 75-79
Malschitzky E., Schilela A., Mattos A. L. G., Garbade P., Gregory R. M., Mattos R. C. (2002) Effect of intra-uterine fluid accumulation during and after foal heat and of different management techniques in the postpartum fertility of throughbred mares. Theriogenology 58, 495-498

Matthews J. C., Ropiha R. T., Butterfield R. M. (1967) The phenomenon of foal heat in mares. Austr. Vet. J. 43, 579-582; DOi 10.1111/j.1751-0813.1967.tb04807.x

McKinnon A. O., Squires E. L. (1988) Equine embryo transfer. Vet. Clin. North Am. Equine Prac. 4, 305-333

Mies Filho A. (1987) Reprodução dos animais e Inseminacao Artificial, 6th ed. Sulina, $423 \mathrm{p}$.

Morris L. H. A., Allen W. R. (2003) Reproductive efficiency of intensively managed Thoroughbred mares in Newmarket. Equine Vet. J. 21, 131-136; DOi 10.2746/042516402776181222

Nagy P., Huszenicza G., Juhasz J., Kulcsar M., Solti L., Reiczigel J., Abaváry K. (1998) Factors influencing ovarian activity and sexual behavior of postpartum mares under farm condition. Theriogenology 50, 1109-1119; DOi 10.1016/S0093-691X(98)00212-X

Sharma S., Davies Morel M. C. G., Dhaliwal G. S. (2010) Factors affecting the incidence of postpartum oestrus, ovarian activity and reproductive performance in Thoroughbred mares bred at foal heat under Indian subtropical conditions. Theriogenology 74, 90-99; DOI 10.1016/i.theriogenology.2010.01.018

van Den Hurk R., Zhao J. (2005) Formation of mammalian oocytes and their growth, differentiation and maturation within ovarian follicles. Theriogenology 63, 1717-1751; DOi 10.1016/i.theriogenology.2004.08.005

Winter G. H. Z., Rubin M. I. B., De La Corte F. D., Silva C. A. M. (2007) Gestacional length and first postpartum ovulation of Criollo mares on a stud farm in Southern Brazil. J. Equine Vet.Sci. 27, 531-534; DOI 10.1016/i.jevs.2007.10.015 